\title{
Chronic exposure to high glucose impairs bradykinin-stimulated nitric oxide production by interfering with the phospholipase-C-implicated signalling pathway in endothelial cells: evidence for the involvement of protein kinase $\mathbf{C}$
}

\author{
Y. Tang ${ }^{1}$ G. D. $\mathbf{L i}^{1}$ \\ ${ }^{1}$ Cardiovascular Research Institute, National University Medical Institutes, National University of Singapore, Singapore
}

\begin{abstract}
Aims/hypothesis. Overwhelming evidence indicates that endothelial cell dysfunction in diabetes is characterised by diminished endothelium-dependent relaxation, but the matter of the underlying molecular mechanism remains unclear. As nitric oxide (NO) production from the endothelium is the major player in endothelium-mediated vascular relaxation, we investigated the effects of high glucose on NO production, and the possible alterations of signalling pathways implicated in this scenario.

Methods. NO production and intracellular $\mathrm{Ca}^{2+}$ levels $\left(\left[\mathrm{Ca}^{2+}\right]_{\mathrm{i}}\right)$ were assessed using the fluorescent probes 4,5-diaminofluorescein diacetate and fura-2 respectively.

Results. Exposure of cultured bovine aortic endothelial cells to high glucose for 5 or 10 days significantly reduced NO production induced by bradykinin (but not by $\mathrm{Ca}^{2+}$ ionophore) in a time- and dose-dependent manner. This was probably due to an attenuation in bradykinin-induced elevations of $\left[\mathrm{Ca}^{2+}\right]_{\mathrm{i}}$ under these conditions, since a close correlation between $\left[\mathrm{Ca}^{2+}\right]_{\mathrm{i}}$ increases and $\mathrm{NO}$ generation was observed in intact bovine aortic endothelial cells. Both bradykinin-pro-
\end{abstract}

moted intracellular $\mathrm{Ca}^{2+}$ mobilisation and extracellular $\mathrm{Ca}^{2+}$ entry were affected. Moreover, bradykinin-induced formation of $\operatorname{Ins}(1,4,5) \mathrm{P}_{3}$, a phospholipase $\mathrm{C}$ product leading to increases in $\left[\mathrm{Ca}^{2+}\right]_{\mathrm{i}}$, was also inhibited following high glucose culture. This abnormality was not attributable to a decrease in inositol phospholipids, but possibly to a reduction in the number of bradykinin receptors. The alterations in NO production, the increases in $\left[\mathrm{Ca}^{2+}\right]_{i}$, and the bradykinin receptor number due to high glucose could be largely reversed by protein kinase $\mathrm{C}$ inhibitors and $\mathrm{D}-\alpha$-tocopherol (antioxidant).

Conclusions/interpretation. Chronic exposure to high glucose reduces NO generation in endothelial cells, probably by impairing phospholipase-C-mediated $\mathrm{Ca}^{2+}$ signalling due to excess protein kinase $\mathrm{C}$ activation. This defect in NO release may contribute to the diminished endothelium-dependent relaxation and thus to the development of cardiovascular diseases in diabetes.

Keywords Antioxidant - Bradykinin · Calcium · Diabetes · Endothelial cells $\cdot$ High glucose $\cdot$

Ins $(1,4,5) \mathrm{P}_{3} \cdot$ Nitric oxide $\cdot$ Phospholipase $\mathrm{C} \cdot$ Protein kinase $\mathrm{C}$.
G. D. Li $(\bowtie)$

Cardiovascular Research Institute,

National University Medical Institutes,

National University of Singapore, Blk MD11 \#02-01,

10 Medical Drive, Singapore 117597, Singapore

E-mail: nmiligd@nus.edu.sg

Tel.: +65-6874-5188, Fax: +65-6773-5461
Abbreviations: BAEC, bovine aortic endothelial cells . $\left[\mathrm{Ca}^{2+}\right]_{\mathrm{i}}$, cytosolic free $\mathrm{Ca}^{2+}$ concentrations $\cdot$ DAF-2/DA, 4,5-diaminofluorescein diacetate $\cdot$ eNOS, endothelial nitric oxide synthase · HBSS, Hanks' balanced salt solution · $\mathrm{IP}_{3}$, inositol 1,4,5-triphosphate $\cdot \mathrm{L}-\mathrm{NAME}, N^{\mathrm{G}}$-nitro-1-arginine methylester $\cdot \mathrm{NO}$, nitric oxide $\cdot \mathrm{PIP}_{2}$, phosphatidylinositol-4,5bisphosphate $\cdot \mathrm{PKC}$, protein kinase $\mathrm{C} \cdot \mathrm{PLC}$, phospholipase $\mathrm{C}$ 


\section{Introduction}

Both microvascular and macrovascular complications occur frequently in poorly controlled diabetes and cause more than $80 \%$ of the overall mortality in diabetic individuals [1]. The molecular mechanisms by which hyperglycaemia leads to these complications are unclear. However, ample data have revealed that endothelium-dependent vascular relaxation is impaired in various types of blood vessels in experimental diabetic animals as well as in both type 1 and type 2 diabetic patients, thereby shown to be an early indicator of endothelium injury $[2,3,4,5,6]$. In addition, diabetes-induced changes in vascular reactivity appear to be a time-dependent phenomenon; an increased relaxation occurs in the early stage of diabetes, while a reduced vasodilation and an increased vasoconstriction occur as the disease progresses $[6,7,8,9]$. It is known that protein kinase $\mathrm{C}$ (PKC) and oxidative stress may be implicated in the pathogenesis of diabetes-related vascular diseases, as application of PKC inhibitors and antioxidants can relieve and prevent their development $[10,11,12,13]$.

The endothelium plays an important role as a paracrine organ in the regulation of vascular tone and other functions. In response to stimulation by receptor agonists (e.g. bradykinin, acetylcholine and ATP) and shear force, these cells synthesise and release a substance originally described as endothelium-derived relaxing factor, which is now believed to be the gas molecule nitric oxide (NO) produced by endothelial nitric oxide synthase (eNOS) [14]. In addition, eNOS activity may be regulated by multiple protein kinases, such as tyrosine kinase, PKC, protein kinase $\mathrm{A}$ and protein kinase $\mathrm{B}$, and by ceramide [15]. NO released from endothelial cells activates guanylate cyclase in adjacent vascular smooth muscle cells, resulting in increased cGMP production, which triggers a cascade of reactions leading to relaxation of the blood vessel [16]. Vasodilation activity in response to exogenous NO remains largely normal in diabetes $[2,3,6]$. Thus, an alteration in NO production might make a key contribution to the deregulation of vascular tone and the pathogenesis of various diabetic vascular diseases [4].

The regulatory mechanisms underlying NO formation in endothelial cells may involve an increase in cytosolic free $\mathrm{Ca}^{2+}$ concentrations $\left(\left[\mathrm{Ca}^{2+}\right]_{\mathrm{i}}\right)$, which is a critical activator of eNOS $[17,18] .\left[\mathrm{Ca}^{2+}\right]_{\mathrm{i}}$ elevation can be a result of the inositol 1,4,5-triphosphate $\left(\mathrm{IP}_{3}\right)$ mediated release of intracellularly stored $\mathrm{Ca}^{2+}$ as well as the stimulated $\mathrm{Ca}^{2+}$ entry through ligand-stimulated, non-voltage-gated ion channels $[18,19,20]$. $\mathrm{IP}_{3}$ is one of the two products derived from hydrolysis of the membrane lipid phosphatidylinositol-4,5-bisphosphate $\left(\mathrm{PIP}_{2}\right)$ via the activation of phospholipase C (PLC) following stimulation of G-protein-coupled receptors by agonists such as bradykinin $[19,21]$. Thus, one possible mechanism for the defective receptor agonist- induced endothelium-dependent vascular relaxation in diabetes is the impairment in the $\mathrm{IP}_{3}-\mathrm{Ca}^{2+}$ signalling pathway. The reduction in NO formation in endothelial cells from diabetic individuals could occur at one or several intervals in this pathway. Although a few studies in cultured cells at different concentrations of high glucose for a short term (1-2 days) found alterations in $\left[\mathrm{Ca}^{2+}\right]_{\mathrm{i}}$ responses and NO formation, the resulting data are conflicting and are not conclusive [7, 22, 23]. Furthermore, little is known about the long-term effect of high glucose on the PLC-mediated signalling pathway. Considering the chronic course of hyperglycaemia, the long-term action of high glucose on cultured endothelial cells would be more relevant for the understanding of the pathogenesis of the dysfunctional endothelium in diabetes. Bradykinin is a $\mathrm{Ca}^{2+}$-mobilising receptor agonist playing an important role in the regulation of endothelium function and widely used as a tool in studies of PLC-activated signalling pathways in endothelial cells, in particular in studies of endothelium-dependent relaxation [24]. In this study, we found that the prolonged exposure of cultured endothelial cells to high glucose specifically reduced NO formation stimulated by this agonist, probably by reducing receptor number and by impairing $\left[\mathrm{Ca}^{2+}\right]_{\mathrm{i}}$ elevation. These high-glucose-induced alterations appear to be implicated in the activation of PKC and the increase of oxidative stress.

\section{Materials and methods}

Materials. Cell culture medium (MCDB 131 and DMEM), antibiotics, FCS and bovine serum were purchased from Invitrogen-Gibco Corporation (Carlsbad, Calif., USA). Cell culture flasks and dishes were obtained from Falcon (Millville, N.J., USA). Fura-2/acetoxymethylester was obtained from Molecular Probes (Eugene, Ore., USA). The 4,5-diaminofluorescein-2 (DAF-2) diacetate and PKC inhibitors (bisindolylmaleimide I and GÖ 6976) were supplied by CalBiochem (La Jolla, Calif., USA). Bradykinin, $\mathrm{NG}^{\mathrm{G}}$-nitro-l-arginine methylester (L-NAME), ionomycin, thapsigargin and D- $\alpha$-tocopherol (vitamin E) were purchased from Sigma (St. Louis, Mo., USA). D-myo- $\left[{ }^{3} \mathrm{H}\right]$ inositol 1,4,5-trisphosphate $\left(\mathrm{IP}_{3}\right)$ assay kit and $\left[{ }^{3} \mathrm{H}\right]$ bradykinin were supplied by Amersham Biosciences (Little Chalfont, UK). Anti-eNOS monoclonal antibody and goat anti-mouse IgG were purchased from Santa Cruz Biotechnology (Santa Cruz, Calif., USA).

Culture and treatment of bovine aortic endothelial cells. Bovine aortic endothelial cells (BAECs; up to passage 16; Clonetics, Walkersville, Md., USA) were first grown to near confluence in MCDB 131 containing 10\% FCS and antibiotics in humidified air $\left(5 \% \mathrm{CO}_{2}\right)$ at $37^{\circ} \mathrm{C}$. Media were replaced every $48 \mathrm{~h}$. The cells were then cultured with control $(5.6 \mathrm{mmol} / \mathrm{l})$ or elevated $(22.2$ or $44.4 \mathrm{mmol} / \mathrm{l})$ concentrations of glucose in the absence or presence of PKC inhibitors for 5 or 10 days, with concomitant lowering of the serum concentration in the medium to $2 \%$ to keep the cells in the quiescent state. Media were replaced every $24 \mathrm{~h}$ during these periods. The cells reached confluence at the time of the experiment. There was no noticeable difference in growth speed/patter and 
no clear indication of cell death among cells cultured at different concentrations of glucose.

In all experiments after cell culture, high concentrations of glucose were not applied in any utilised medium or solution, and PKC inhibitors were not present. This was to avoid possible acute effects of high glucose or PKC inhibitors on endothelial cell function.

Measurement of NO production. NO generation in living cells can be monitored using a membrane-permeable fluorescent indicator, 4,5-diaminofluorescein diacetate (DAF-2/DA) [25]. BAEC suspensions were obtained by gentle trypsinisation and the detached cells were recovered in spinners in DMEM containing $2 \%$ FCS for $2.5 \mathrm{~h}$. Cells were then incubated with $2 \mathrm{nmol} / \mathrm{l} \mathrm{DAF-2/DA}$ for $30 \mathrm{~min}$ at $37^{\circ} \mathrm{C}$ in the dark. DAF-2loaded cells were resuspended in DMEM. Aliquots of cells $\left(5 \times 10^{6}\right.$ in $\left.200 \mu \mathrm{l}\right)$ were added to the 96 -well black plate. After leaving the plate at $37^{\circ} \mathrm{C}$ for $15 \mathrm{~min}$, stimulants were added and the plate was incubated for up to $6 \mathrm{~h}$. The fluorescence generated by NO production was monitored by a fluorescent plate reader (Spectramax microplate spectrofluorometer; Molecular Devices, Sunnyvale, Calif., USA) at excitation using emission wavelengths of 485 and $515 \mathrm{~nm}$ respectively. The results were expressed as fluorescence intensity (arbitrary units).

Determination of eNOS by western blotting. BAECs cultured at different concentrations of glucose were homogenised. The extract samples $(40 \mu \mathrm{g}$ protein each) were subject to SDSPAGE and transferred onto nitrocellulose membranes as described previously [26]. The membranes were hybridised with an anti-eNOS monoclonal antibody (1:1000 dilution) and then with goat anti-mouse IgG (1:2000 dilution). Blotting bands were visualised by autoluminography after a procedure of enhanced chemiluminescence development.

Measurement of [Ca2+]i. As previously described [27], $\left[\mathrm{Ca}^{2+}\right]_{\mathrm{i}}$ was measured using the fura-2 technique. Briefly, cultured BAECs were harvested after gentle trypsinisation, centrifuged, and resuspended in DMEM containing $2 \%$ FCS. After incubation in a spinner for $2.5 \mathrm{~h}$ at $37^{\circ} \mathrm{C}$, cells were loaded with $1 \mu \mathrm{mol} / \mathrm{l}$ fura-2/AM for $30 \mathrm{~min}$. Following two washes, BAECs were resuspended in a final concentration of $1.25 \times 10^{6}$ cells $/ \mathrm{ml}$ in a mixture of HEPES ( $\left.20 \mathrm{mmol} / \mathrm{l}\right)$-buffered KRB and DMEM with $2 \%$ FCS (1:2, v/v). Aliquots of cell suspensions in cuvettes containing $2 \mathrm{ml}$ HEPES-buffered KRB solution were put in a thermostatically controlled holder equipped with a stirrer. Fluorescence signals were recorded by ratio fluorometry using a spectrofluorometer (Perkin-Elmer Life and Analytical Sciences, Boston, Mass., USA; LS-50B) with an emission wavelength of $515 \mathrm{~nm}$ at alternate $340 / 380 \mathrm{~nm}$ excitation wavelengths, and calibrated into $\left[\mathrm{Ca}^{2+}\right]_{\mathrm{i}}$ values using the equation previously described [27].

Measurement of IP3. The activation of PLC was examined by measuring one of its products $\left(\mathrm{IP}_{3}\right)$. BAECs were cultured in 24-well plates at different concentrations of glucose. On the day of the experiments, cells were washed twice with KRB. After a 15 -min equilibration period in $0.3 \mathrm{ml} \mathrm{KRB}$ per well at $37^{\circ} \mathrm{C}$, cells were stimulated by adding $1 \mu \mathrm{mol} / \mathrm{l}$ (final) bradykinin for 5 or $60 \mathrm{~s}$. Stimulation was stopped and cells were lysed by adding $\mathrm{HClO}_{4}(10 \%$; v/v) at the appropriate time points. Extraction and measurement of $\mathrm{IP}_{3}$ levels in the samples were performed according to the manufacturer's protocol using a radioactive ligand binding assay system (Amersham Biosciences; catalogue no. TRK 1000).
Assessment of bradykinin binding to its receptor. Binding of bradykinin to its receptors in BAECs was assessed by radioligand saturation binding assay [21]. Cells grown in 6-well culture plates under specified culture conditions were washed twice with ice-cold PBS and rinsed once with binding buffer (modified Hanks' balanced salt solution (HBSS); replacement of $120 \mathrm{mmol} / \mathrm{l} \mathrm{NaCl}$ with $\mathrm{N}$-methyl-D-glucamine; reduction by half of the concentrations of $\mathrm{CaCl}_{2}, \mathrm{MgCl}_{2}$, and $\mathrm{MgSO}_{4}$; supplemented with $0.1 \% \mathrm{BSA}, 5.6 \mathrm{mmol} / \mathrm{l}$ glucose, $2 \mathrm{~g} / \mathrm{l}$ bacitracin and $10 \mathrm{mmol} / \mathrm{l} \mathrm{HEPES}$; $\mathrm{pH}$ 7.4). After $15 \mathrm{~min}$ of equilibration on ice, cells were incubated in $1.5 \mathrm{ml}$ HBSS containing $0.5 \mathrm{nmol} / 1\left[{ }^{3} \mathrm{H}\right]$ bradykinin $(3.33-4.44 \mathrm{MBq} / \mathrm{mmol})$ with different concentrations of unlabelled bradykinin $(0.1-50 \mathrm{nmol} / \mathrm{l})$ for $2 \mathrm{~h}$ at $4{ }^{\circ} \mathrm{C}$. Non-specific binding was assessed in the presence of $5 \mu \mathrm{mol} / \mathrm{l}$ cold bradykinin. The medium was then removed and cells were rapidly rinsed four times in ice-cold rinsing buffer (modified HBSS containing $0.2 \%$ BSA). Subsequently, cells were detached by trypsinisation and transferred to scintillation vials. After mixing thoroughly with scintillation cocktail, radioactivity in the samples was determined by a beta counter. Data analysis was undertaken as previously described [28].

Measurement of inositol phospholipids. After BAECs seeded in $75-\mathrm{cm}^{2}$ flasks cultured with control or high glucose for 10 days, cells were incubated in $4 \mathrm{ml}$ phosphate-free DMEM medium containing $0.37 \mathrm{MBq} / \mathrm{ml}{ }^{32} \mathrm{P}_{\mathrm{i}}$ for $2 \mathrm{~h}$. After they were washed, cells were harvested by trypsinisation and transferred to glass tubes. Cell pellets from centrifugation were subject to repeated extraction with $\mathrm{CHCl}_{3}-\mathrm{CHOH}-2.4 \mathrm{~N} \mathrm{HCl}(1.5: 1: 1.5)$ to obtain total cellular lipids [29]. Phospholipid standards and extracted lipid samples were loaded on preactivated TLC plates, which were developed successively in two different solvent systems [30]. The ${ }^{32} \mathrm{P}$-labelled lipids were visualised by autoradiography and the spots corresponding with $\mathrm{PIP}_{2}$, PIP and PI were scraped into vials. After thorough mixing with scintillation cocktail, the radioactivity was determined using a beta counter.

Statistical analysis. Results are expressed as means \pm SEM. Statistical evaluation of the data was performed using an unpaired two-tailed t test and ANOVA. Differences were considered significant when the $\mathrm{p}$ value was less than 0.05 .

\section{Results}

Chronic exposure to high glucose impairs agonist-induced NO formation. Bradykinin $(1 \mu \mathrm{mol} / \mathrm{l})$ induced an increase in NO production almost linearly over a 6-h period of incubation in control BAECs (Fig. 1a). Such stimulated NO generation could be blocked by $100 \mu \mathrm{mol} / \mathrm{l} \mathrm{L}-\mathrm{NAME}$, an inhibitor of eNOS, indicating that the detected fluorescent signals reflected the cellular NO production, therefore validating the method. Exposure of BAECs to high glucose impaired bradykinin-induced NO production in a time- and concentration-dependent manner (Fig. 1). For instance, the NO formation over 120 min of stimulation was significantly reduced by $31 \%$ and $39 \%(n=7, p<0.01)$ after 5-day culture at 22.2 and $44.4 \mathrm{mmol} / \mathrm{l}$ glucose respectively (Fig. 1b). Further reduction of bradykinin-stimulated NO production over the same period $(-32 \%$ and $-49 \%$ respectively) occurred following 10 days of 

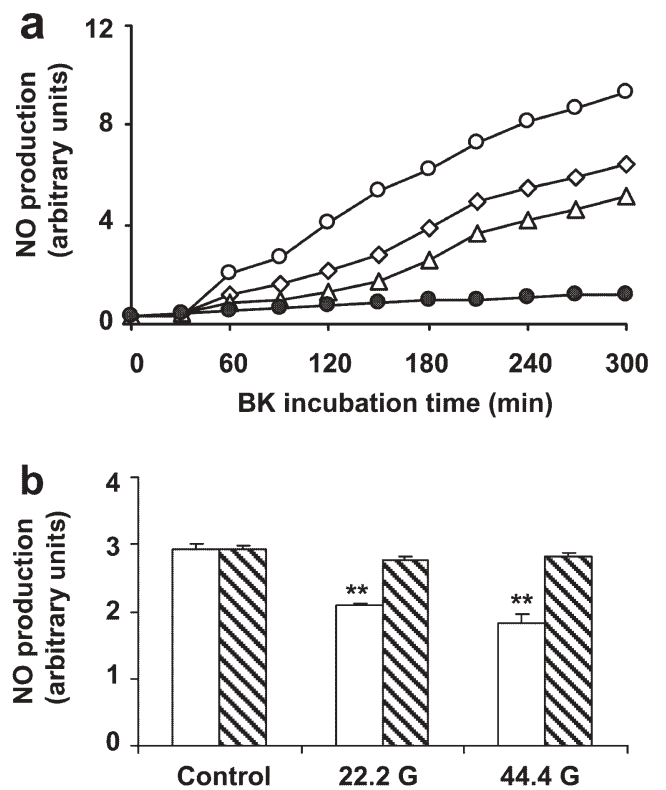

Fig. 1. Effect of high glucose culture on NO production in BAECs. BAECs were cultured with control $(5.6 \mathrm{mmol} / \mathrm{l})$ or elevated concentrations of glucose $(G)$, either 22.2 or $44.4 \mathrm{mmol} / \mathrm{l}$, for 5 days (a, b) or 10 days $(\mathbf{c}, \mathbf{d})$. a, c. Bradykinin $(\mathrm{BK} ; 1$ umol/l)-stimulated NO production was measured in cell suspensions. The basal NO levels in the absence of stimulants remained almost unchanged over the 6-h incubation period (data not shown). Each data point is the average of seven experiments. Open circles, control cells; diamonds, cultured with $22.2 \mathrm{mmol} / \mathrm{l}$ glucose; triangles, cultured with $44.4 \mathrm{mmol} / \mathrm{l}$ glucose; closed circles, control cells in the presence of L-NAME during bradykinin stimulation. b, d. NO production during $120 \mathrm{~min}$ of stimulation by $1 \mu \mathrm{mol} / \mathrm{l}$ bradykinin (open bars) or by $2 \mu \mathrm{mol} / 1$ ionomycin (hatched bars). Values are means \pm SEM of seven experiments. $* * p<0.01$ vs control ( $t$ test)

culture with high glucose (Fig. 1c, d). Similar inhibitory effects were also observed on NO production induced by purinergic stimulation with $10 \mu \mathrm{mol} / \mathrm{l}$ ATP, another PLC activator (data not shown). In contrast, high glucose culture did not alter ionomycin $\left(\mathrm{a} \mathrm{Ca}^{2+}\right.$ ionophore)-induced NO production in BAECs (Fig. 1b, d). The observation that high glucose culture selectively inhibited NO production induced by receptor agonists suggests the existence of impairment(s) at some stage of the signalling transduction pathway, from stimulation of transmembrane receptors to activation of eNOS.

Sustained high glucose culture has no effect on eNOS protein mass. The decrease in bradykinin-induced NO production in high-glucose-cultured BAECs could be due to a reduction in eNOS mass and/or to its activity. A possible change in eNOS mass through chronic high glucose culture was examined by western blotting. However, no significant alteration in eNOS mass occurred in BAECs cultured with high glucose for 5 or 10 days (data not shown), suggesting that the activ-
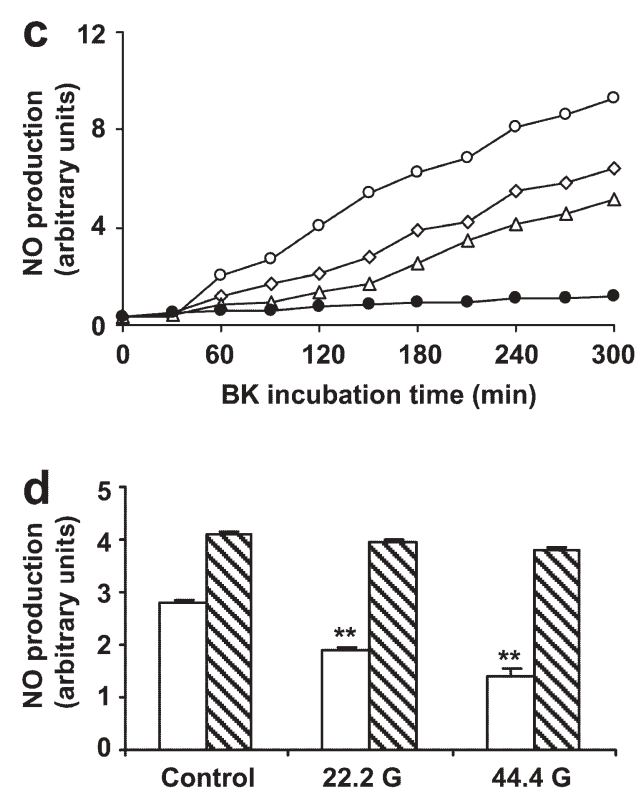

ity, rather than the mass, of eNOS in BAECs is affected by high glucose treatment.

NO production in BAECs is correlated with an increase in $[\mathrm{Ca} 2+] i$. The relationship between $\left[\mathrm{Ca}^{2+}\right]_{\mathrm{i}}$ and $\mathrm{NO}$ production in BAECs was examined by applying various doses of ionomycin. $\left[\mathrm{Ca}^{2+}\right]_{i}$ were elevated concomitantly in a concentration-dependent fashion (Fig. 2a). Upon stimulation by the same concentrations of the $\mathrm{Ca}^{2+}$ ionophore, $\mathrm{NO}$ generation in BAECs was increased in a dose-dependent manner (Fig. 2b). A close correlation between ionomycinstimulated NO production and ionomycin-induced peaks in $\left[\mathrm{Ca}^{2+}\right]_{\mathrm{i}}$ was observed (Fig. 2c).

The role of increased $\left[\mathrm{Ca}^{2+}\right]_{\mathrm{i}}$ in bradykinin-stimulated NO production in BAECs was studied in the presence or absence of free $\mathrm{Ca}^{2+}$ in the extracellular space. When $\mathrm{Ca}^{2+}$ levels were lowered to approximately $100 \mathrm{nmol} / \mathrm{l}$ by adding EGTA (a $\mathrm{Ca}^{2+}$ chelator) to the medium, bradykinin-stimulated NO production in such nominal $\mathrm{Ca}^{2+}$-free medium for 90 min was completely abolished (Fig. 2d). Afterwards, bringing extracellular free $\mathrm{Ca}^{2+}$ back to normal levels restored bradykinin-induced NO formation (Fig. 2d). Thus, our observations clearly indicate that an increase in $\left[\mathrm{Ca}^{2+}\right]_{\mathrm{i}}$ via $\mathrm{Ca}^{2+}$ entry is essential for bradykinin to induce NO production.

High glucose culture reduces receptor-agonistinduced increases in $[\mathrm{Ca} 2+] \mathrm{i}$ in BAECs. The above results prompted us to examine the $\left[\mathrm{Ca}^{2+}\right]_{\mathrm{i}}$ profile in BAECs following high glucose culture. In control cells, bradykinin stimulation resulted in a rapid increase in $\left[\mathrm{Ca}^{2+}\right]_{\mathrm{i}}$ from $107 \pm 26 \mathrm{nmol} / \mathrm{l}$ to a peak of $542 \pm 27 \mathrm{nmol} / \mathrm{l}$. In cells pretreated for 5 days with high glucose, the ability of bradykinin to elevate $\left[\mathrm{Ca}^{2+}\right]_{\mathrm{i}}$ was markedly inhibited; the average increase in $\left[\mathrm{Ca}^{2+}\right]_{\mathrm{i}}$ during the first $30 \mathrm{~s}$ decreased to $338 \pm 11 \mathrm{nmol} / \mathrm{l}$ at $22.2 \mathrm{mmol} / \mathrm{l}$ and to $236 \pm 15 \mathrm{nmol} / \mathrm{l}$ at 


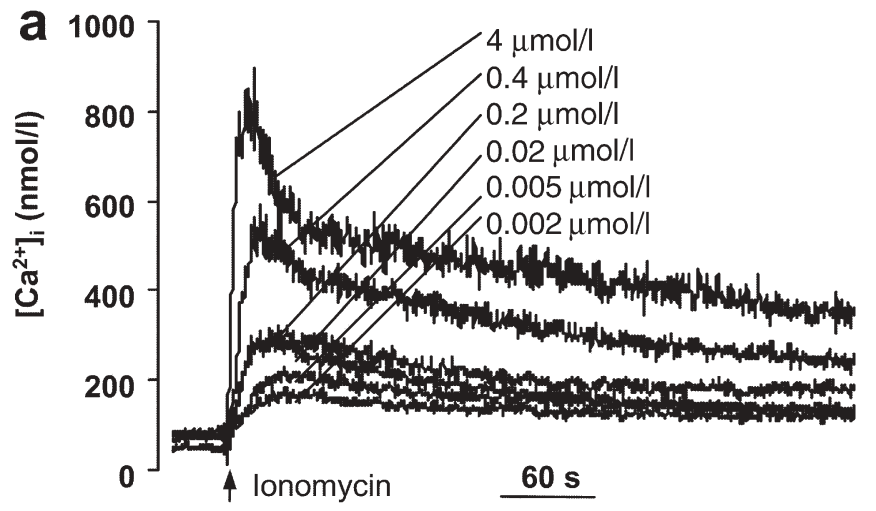

b
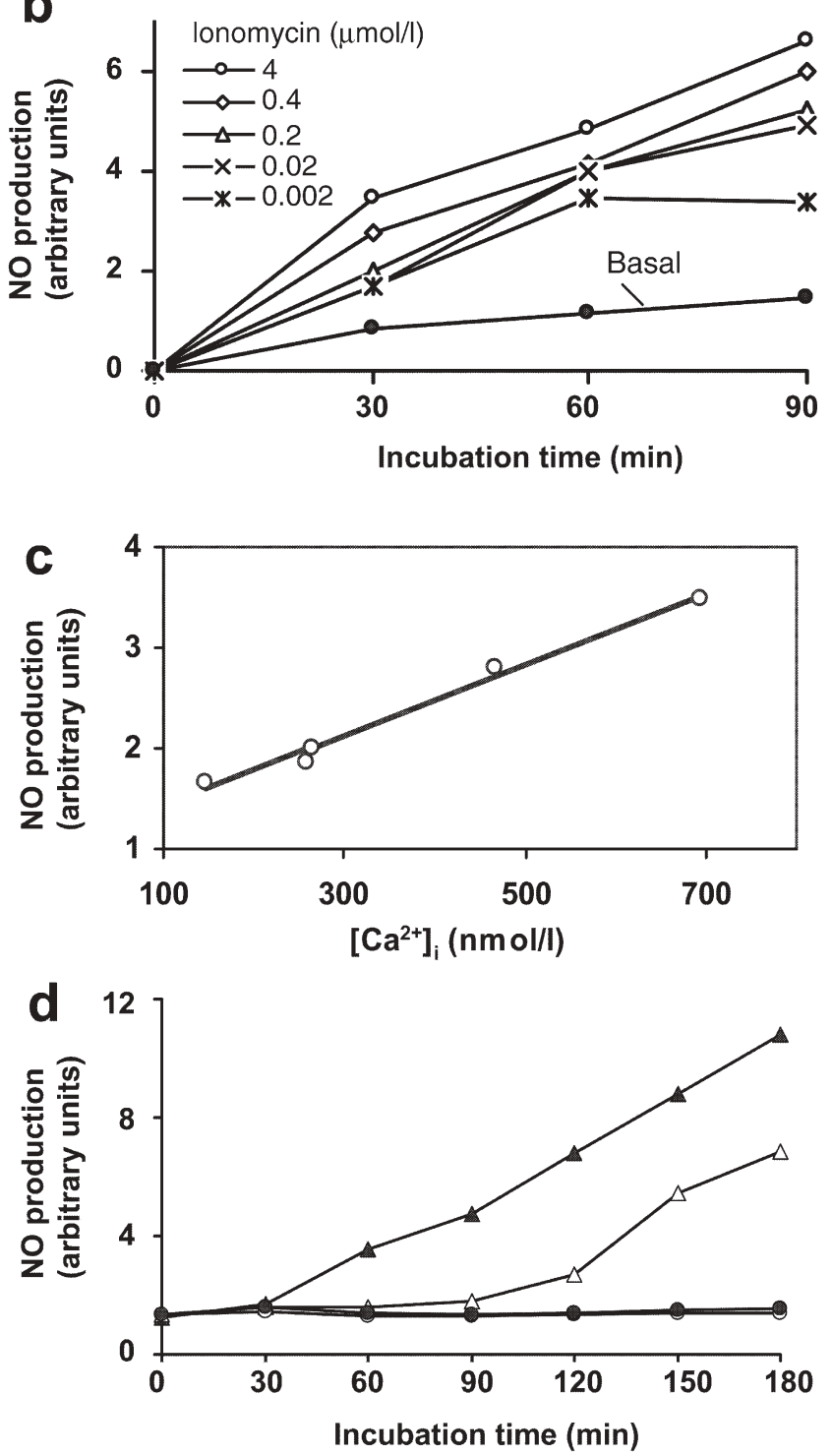

Fig. 2. The relationship between $\left[\mathrm{Ca}^{2+}\right]_{\mathrm{i}}$ and NO production. a. $\left[\mathrm{Ca}^{2+}\right]_{\mathrm{i}}$ in BAECs was elevated to various levels by different concentrations $(0.002$ to $4 \mu \mathrm{mol} / \mathrm{l})$ of ionomycin. Each trace is the average of three to four experiments. b. NO formation stimulated by ionomycin at the same concentrations as in a. Each data point is the average of four experiments. c. Correlation of ionomycin-stimulated NO production (30 min of incubation) with ionomycin-induced peaks in $\left[\mathrm{Ca}^{2+}\right]_{\mathrm{i}}$. d. Require-
$44.4 \mathrm{mmol} / \mathrm{l}$, which corresponds with a reduction of $38 \%$ and $56 \%(p<0.01)$ respectively (Fig. 3a, c). Exposure to high glucose for 10 days further reduced bradykinin-induced increases in $\left[\mathrm{Ca}^{2+}\right]_{\mathrm{i}}$ by $61 \%$ and $68 \%$ after culture in 22.2 and $44.4 \mathrm{mmol} / \mathrm{l}$ glucose respectively $(p<0.01$; Fig. $3 b, c)$. However, basal $\left[\mathrm{Ca}^{2+}\right]_{\mathrm{i}}$ were not affected by high glucose culture. These results suggest that reduced NO production following bradykinin stimulation in high-glucose-cultured BAECs could be due to a diminished $\left[\mathrm{Ca}^{2+}\right]_{\mathrm{i}}$ response.

In contrast, increases in $\left[\mathrm{Ca}^{2+}\right]_{\mathrm{i}}$ induced by ionomycin $(2 \mu \mathrm{mol} / \mathrm{l})$ were not affected by 10 days of high glucose culture (data not shown). This may explain why high glucose did not interfere with ionomycinstimulated NO production (Fig. 1b, d).

High glucose culture inhibits bradykinin-induced $\mathrm{Ca} 2+$ mobilisation and Ca2+ influx. Receptor agonists such as bradykinin induce increases in $\left[\mathrm{Ca}^{2+}\right]_{\mathrm{i}}$ in two ways: $\mathrm{Ca}^{2+}$ mobilisation from intracellular stores, and $\mathrm{Ca}^{2+}$ influx from extracellular space $[19,20]$. These two events can be examined separately as shown in Fig. 4. The former is assessed by lowering the extracellular free $\mathrm{Ca}^{2+}$ level by EGTA, and the latter is determined by restoring extracellular free $\mathrm{Ca}^{2+}$ to the normal level. After 5 days of culture with 22.2 or $44.4 \mathrm{mmol} / \mathrm{l}$ glucose, bradykinin-induced $\mathrm{Ca}^{2+}$ mobilisation was reduced by $12 \%$ and $20 \%(p<0.01$, $n=10)$ respectively, while the $\mathrm{Ca}^{2+}$ influx was reduced by $17 \%$ and $30 \% \quad(p<0.01, n=10)$ respectively (Fig. 4a). Further reduction in bradykinin-induced $\mathrm{Ca}^{2+}$ mobilisation and $\mathrm{Ca}^{2+}$ influx was observed after 10 days of culture under these conditions; the former was diminished by $20 \%$ and $31 \%(p<0.01, n=10)$ respectively, and the latter was reduced by $26 \%$ and $46 \%(p<0.01, n=10)$ respectively (Fig. $4 \mathrm{~b})$. These data indicate that protracted high glucose treatment significantly inhibited both $\mathrm{Ca}^{2+}$ mobilisation and $\mathrm{Ca}^{2+}$ influx in BAECs, albeit with a more severe effect on the latter.

Also examined was the increase in $\left[\mathrm{Ca}^{2+}\right]_{\mathrm{i}}$ induced by thapsigargin, which mobilises $\mathrm{Ca}^{2+}$ from $\mathrm{IP}_{3}$-sensitive intracellular $\mathrm{Ca}^{2+}$ stores through inhibition of $\mathrm{Ca}^{2+}-$ ATPase in the stores [31]. The results revealed that 10 days of high glucose culture did not affect

ment of $\mathrm{Ca}^{2+}$ entry from extracellular space for bradykinin-induced NO production. In normal medium (with $1.5 \mathrm{mmol} / \mathrm{l}$ $\mathrm{Ca}^{2+}$ ), bradykinin-stimulated NO production in BAECs was nearly linear during the period in which it was detected (closed triangles). Bradykinin-induced NO formation was blocked when extracellular free $\mathrm{Ca}^{2+}$ level was reduced to nominal free $\mathrm{Ca}^{2+}$ level by adding $3 \mathrm{mmol} / \mathrm{l}$ EGTA (open triangles; first $90 \mathrm{~min}$ ). However, adding $3 \mathrm{mmol} / \mathrm{C} \mathrm{Ca}^{2+}$ to the solution restored NO production at the normal rate (open triangles; beyond $90 \mathrm{~min}$ ). Open circles, basal NO level without stimulation; closed circles, bradykinin stimulation in the presence of $3 \mathrm{mmol} / \mathrm{l}$ EGTA throughout the 180-min period 

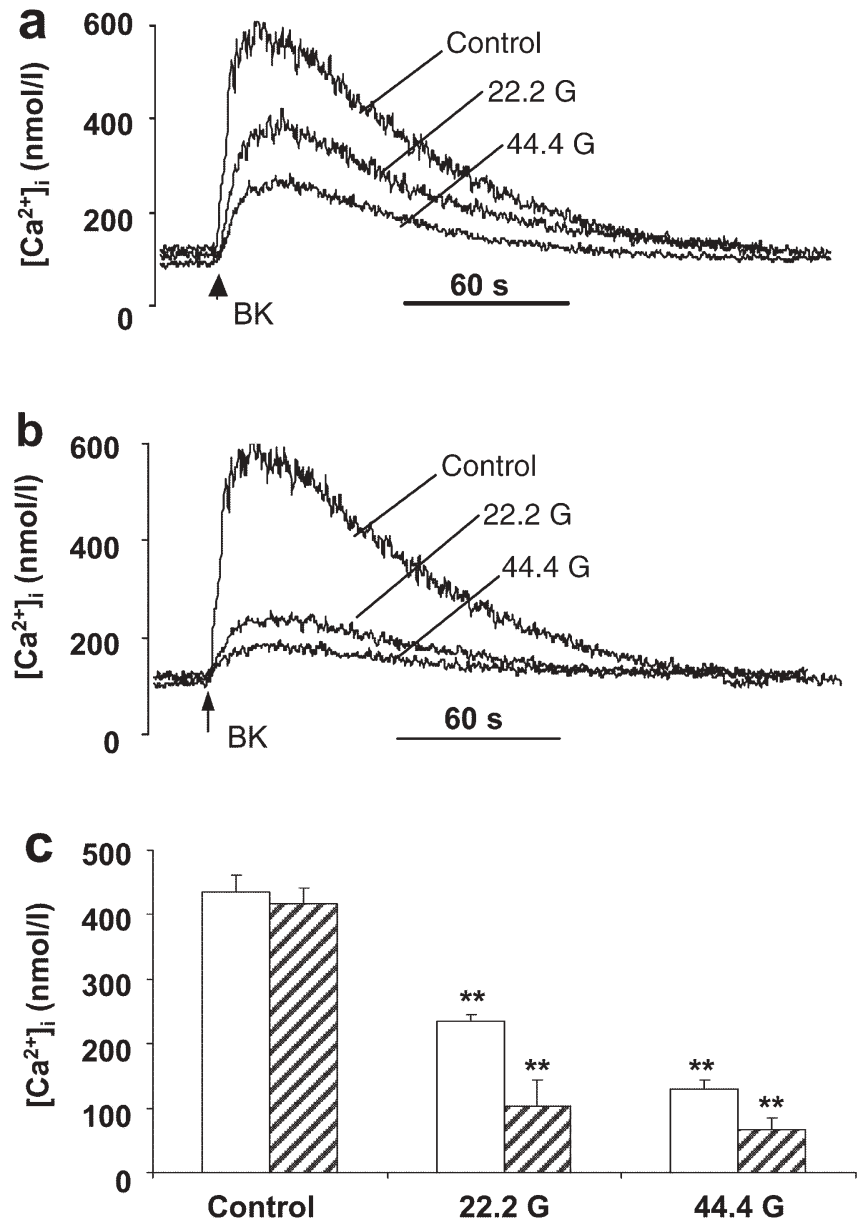

Fig. 3. Effect of high glucose culture on bradykinin-induced increases in $\left[\mathrm{Ca}^{2+}\right]_{\mathrm{i}}$ in BAECs. Bradykinin (BK; $\left.1 \mu \mathrm{mol} / \mathrm{l}\right)$-induced increases in $\left[\mathrm{Ca}^{2+}\right]_{\mathrm{i}}$ in BAECs cultured for 5 days $(\mathbf{a})$ or 10 days (b) at control $(5.6 \mathrm{mmol} / \mathrm{l})$ or high $(22.2$ or $44.4 \mathrm{mmol} / \mathrm{l}$ ) concentrations of glucose $(\mathrm{G})$ were measured in cell suspensions using the fluorescent $\mathrm{Ca}^{2+}$ probe fura- 2 as described in the Materials and methods section. Each trace is the superposition of 11 experiments. c. The average increases in $\left[\mathrm{Ca}^{2+}\right]_{\mathrm{i}}$ during the initial $30 \mathrm{~s}$ of bradykinin stimulation. Bar values are means \pm SEM. $* * p<0.01$ vs control $(t$ test). Open bars, 5 days of culture; hatched bars, 10 days of culture

thapsigargin-induced increases in $\left[\mathrm{Ca}^{2+}\right]_{\mathrm{i}}$ (data not shown), suggesting that the $\mathrm{IP}_{3}$-releasable $\mathrm{Ca}^{2+}$ pool remained intact. This observation demonstrated again that only receptor-agonist-elicited $\left[\mathrm{Ca}^{2+}\right]_{i}$ responses were impeded by high glucose.

High glucose culture attenuates both basal and bradykinin-stimulated IP3 formation in BAECs. As PLC-activating receptor agonists induce an increase in $\left[\mathrm{Ca}^{2+}\right]_{\mathrm{i}}$ by generating $\mathrm{IP}_{3}[19,21]$, the possible effect of high glucose on this second messenger was examined. The basal level of $\mathrm{IP}_{3}$ in control BAECs was $0.90 \pm 0.06 \mathrm{pmol} / \mathrm{mg}$ proteins. Culture with 22.2 and $44.4 \mathrm{mmol} / \mathrm{l}$ glucose for 10 days markedly decreased the basal $\mathrm{IP}_{3}$ levels to $0.44 \pm 0.03$ and $0.46 \pm 0.05 \mathrm{pmol} / \mathrm{mg}$ proteins $(p<0.01)$ respectively
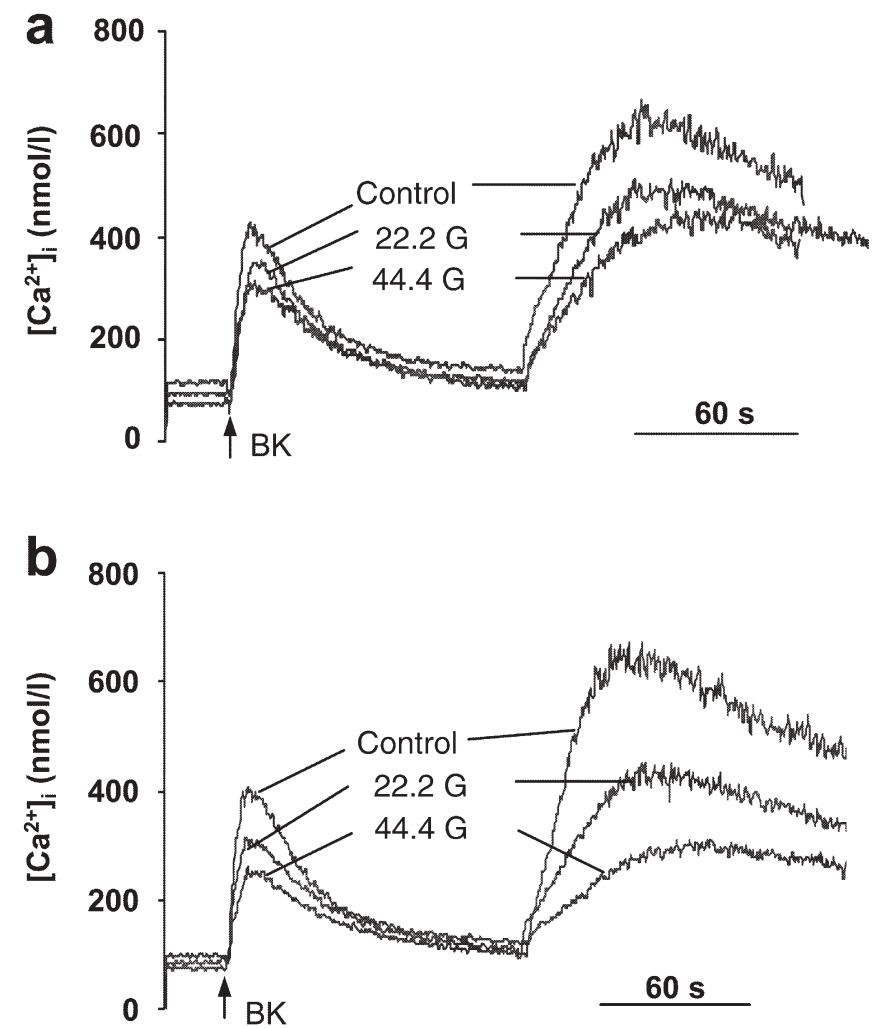

Fig. 4. Effects of high glucose culture on bradykinin (BK)stimulated $\mathrm{Ca}^{2+}$ mobilisation and $\mathrm{Ca}^{2+}$ influx in BAECs. Cells were cultured with control $(5.6 \mathrm{mmol} / \mathrm{l})$ or high $(22.2$ or $44.4 \mathrm{mmol} / \mathrm{l}$ ) concentrations of glucose $(\mathrm{G})$ for 5 days (a) or 10 days (b). $\left[\mathrm{Ca}^{2+}\right]_{\mathrm{i}}$ was measured by loading the fluorescent $\mathrm{Ca}^{2+}$ probe (fura-2) in the cells. Bradykinin $(1 \mu \mathrm{mol} / \mathrm{l})$-induced $\mathrm{Ca}^{2+}$ mobilisation from intracellular stores was determined by chelating $\mathrm{Ca}^{2+}$ in extracellular buffer to nominal free $\mathrm{Ca}^{2+}$ levels by adding $3 \mathrm{mmol} / \mathrm{l}$ EGTA, whereas bradykinin-promoted $\mathrm{Ca}^{2+}$ influx was detected by restoration of extracellular free $\mathrm{Ca}^{2+}$ to the normal level by adding $3 \mathrm{mmol} / \mathrm{l} \mathrm{Ca}^{2+}$ to the solution. Each trace is the superposition of ten experiments ( $t$ test)

(Fig. 5). Moreover, bradykinin-stimulated $\mathrm{IP}_{3}$ production (increase vs basal) was also significantly reduced by $29 \%$ and $48 \%$ respectively during $5 \mathrm{~s}$ of stimulation, and by $46 \%$ and $64 \%$ respectively during $60 \mathrm{~s}$ of incubation (Fig. 5).

No effect of high glucose culture on inositol phospholipids in BAECs. The decreased $\mathrm{IP}_{3}$ production following bradykinin stimulation in high-glucose-cultured cells could result from a reduction in the substrate for PLC. Thus, the contents of inositol phospholipids in these cells were measured by thin-layer chromatography. Culture of BAECs for 10 days at 22.2 or $44.4 \mathrm{mmol} / \mathrm{l}$ glucose did not cause significant changes in the contents of all three inositol phospholipids: PI, PIP and PIP $_{2}$ (Fig. 6).

Prolonged high glucose culture decreases the number of bradykinin receptors in BAECs. The possible effects of high glucose culture on PLC-coupled recep- 


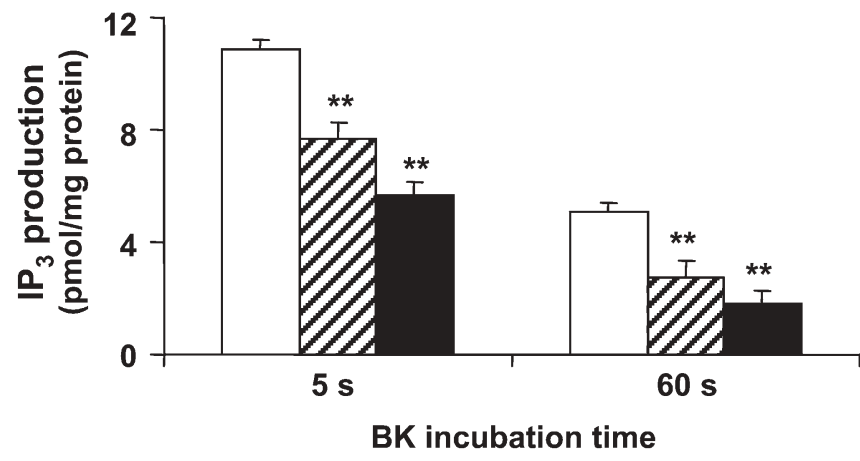

Fig. 5. Effects of high glucose on bradykinin (BK)-induced $\mathrm{IP}_{3}$ formation in BAECs. Cells exposed to control and high concentrations of glucose for 10 days were incubated with $2 \mu \mathrm{mol} / 1$ bradykinin in $\mathrm{KRB}$ for 5 or $60 \mathrm{~s}$ at $37^{\circ} \mathrm{C}$. $\mathrm{IP}_{3}$ in the cells was extracted and measured by radioligand binding assay. Values are means \pm SEM of three experiments. $* * p<0.01$ vs control ( $t$ test). Open bars, control cells; hatched bars, cultured with $22.2 \mathrm{mmol} / \mathrm{l}$ glucose; closed bars, cultured with $44.4 \mathrm{mmol} / \mathrm{l}$ glucose

a
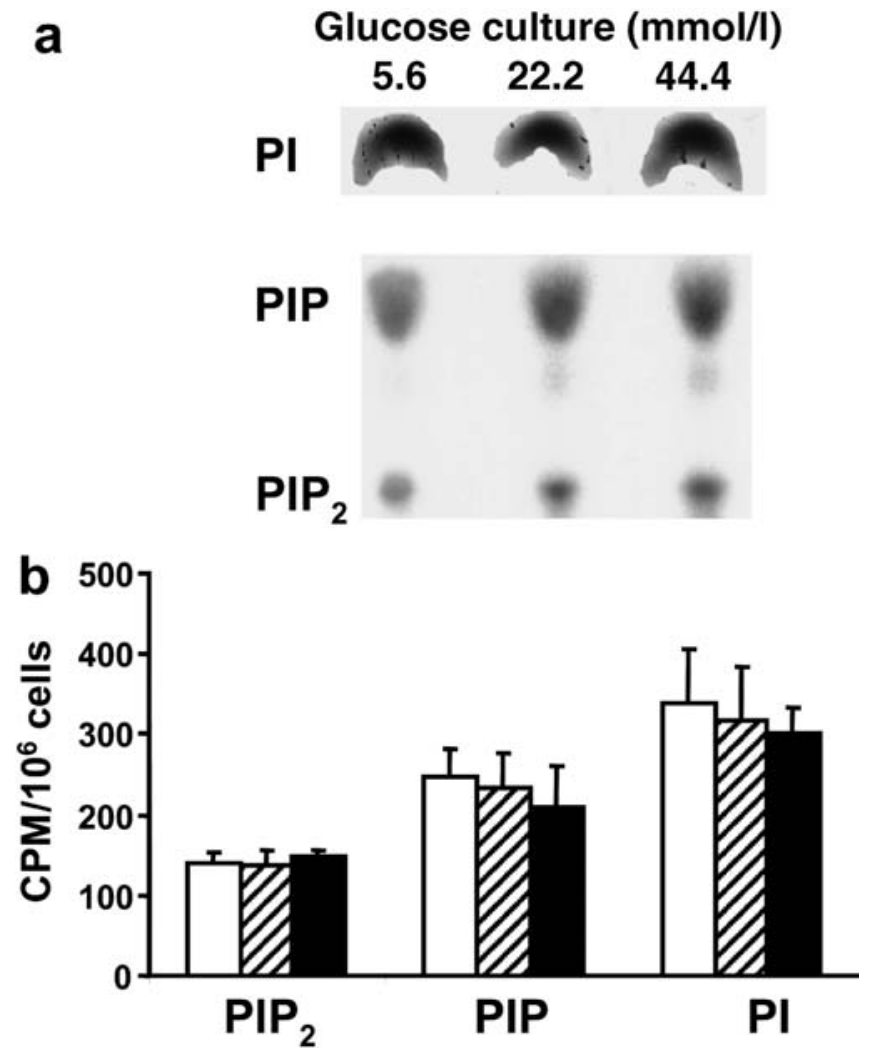

Fig. 6. Effect of high glucose culture on PI, PIP and $\mathrm{PIP}_{2}$ in BAECs. BAECs were cultured with either control or high glucose for 10 days. a. After labelling with ${ }^{32} \mathrm{P}$, cell lipids were extracted, separated by thin-layer chromatography, and autoradiographied as described in the Materials and methods section. b. Statistical analysis of the contents of ${ }^{32} \mathrm{P}$-labelled inositol phospholipids. Data are the means \pm SEM of three independent experiments in duplicate ( $t$ test). Open bars, control cells; hatched bars, cultured with $22.2 \mathrm{mmol} / 1$ glucose; closed bars, cultured with $44.4 \mathrm{mmol} / \mathrm{l}$ glucose
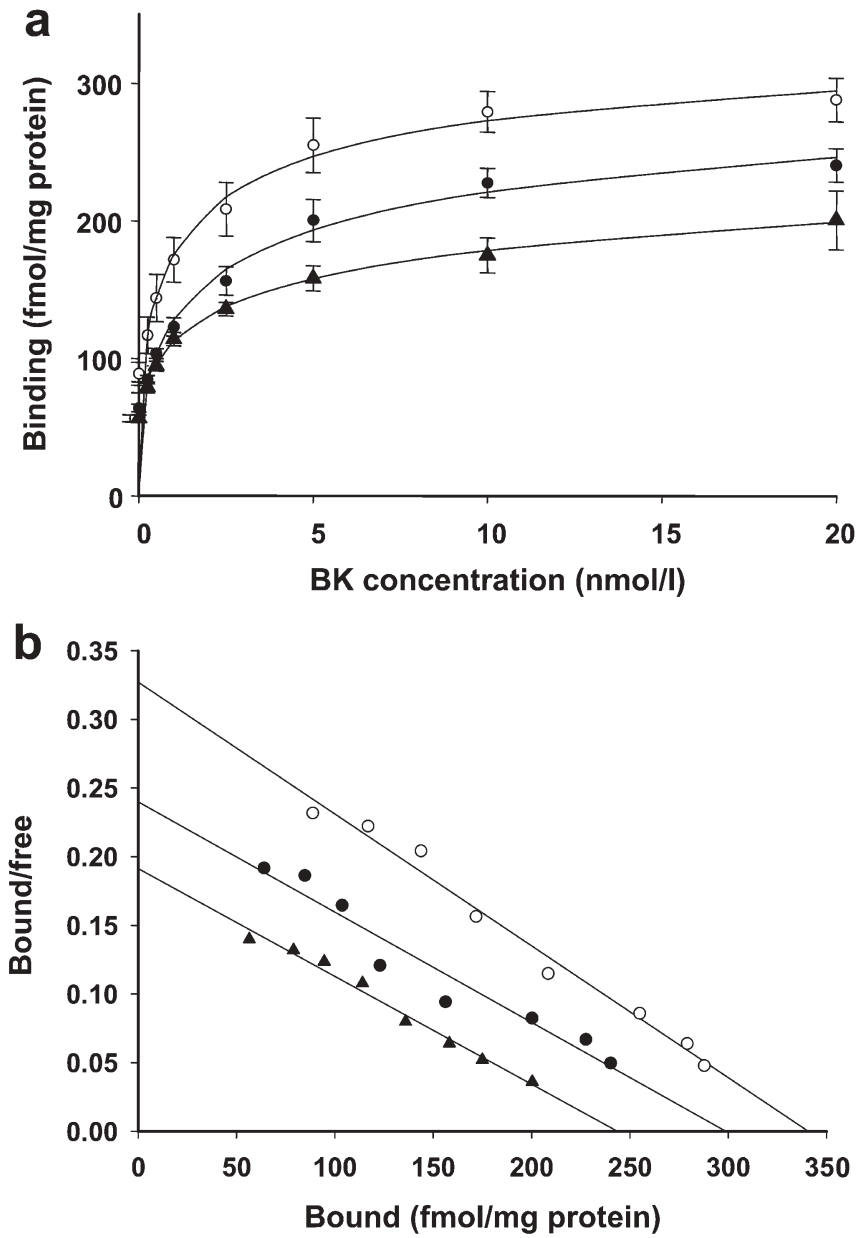

Fig. 7. Effect of high glucose culture on the bradykinin (BK) receptor in BAECs. Saturation binding (a) and Scatchard plot (b) analyses were performed by a non-linear-curve-fitting program (Sigma Plot; SPSS, Chicago, Ill., USA) to determine the dissociation constants and the total number of bradykinin receptors. Data are from four independent observations ( $t$ test). Open circles, control cells; closed circles, cultured with $22.2 \mathrm{mmol} / \mathrm{l}$ glucose; triangles, cultured with $44.4 \mathrm{mmol} / \mathrm{l}$ glucose

tors were also investigated. Performance of radioligand binding assay detected only one type of bradykinin receptor in BAECs with a $\mathrm{K}_{\mathrm{d}}$ of $1.1 \pm 0.09 \mathrm{nmol} / \mathrm{l}$ and a total number of receptors of $345 \pm 18 \mathrm{fmol} / \mathrm{mg}$ protein, as all plots fitted a single receptor model (Fig. 7). High glucose culture for 10 days significantly reduced the total number of bradykinin receptors by $22 \%$ and $29 \%$ at 22.2 and $44.4 \mathrm{mmol} / \mathrm{l}$ glucose respectively (declined to $270 \pm 16$ and $245 \pm 23 \mathrm{fmol} / \mathrm{mg}$ protein respectively; $p<0.01$ vs control; Fig. $7 b$ ). However, the affinity of bradykinin receptors $\left(\mathrm{K}_{\mathrm{d}}\right)$ was not affected $(1.3 \pm 0.1 \mathrm{nmol} / 1$ and $1.1 \pm 0.1 \mathrm{nmol} / 1$ at 22.2 and $44.4 \mathrm{mmol} / \mathrm{l}$ glucose respectively; $p>0.05$ vs control) under these conditions (Fig. 7b).

Reversal of impairments by PKC inhibitors. PKC inhibitors reverse impairments in agonist-induced (i) NO formation, (ii) increases in $\left[\mathrm{Ca}^{2+}\right]_{\mathrm{i}}$, and (iii) reduc- 
Table 1. PKC inhibitors reverse high-glucose-induced inhibition of NO production induced by bradykinin

\begin{tabular}{|c|c|c|c|c|}
\hline \multirow[t]{2}{*}{ Condition (glucose) } & \multicolumn{4}{|c|}{ Co-treatment } \\
\hline & None & $\begin{array}{l}\text { Bisindolylmaleimide } \\
(10 \mu \mathrm{mol} / \mathrm{l})\end{array}$ & GÖ6976 (20 nmol/l) & $\begin{array}{l}\text { D- } \alpha \text {-tocopherc } \\
(100 \mu \mathrm{mol} / \mathrm{l})\end{array}$ \\
\hline \multicolumn{5}{|c|}{ Co-treatment for 5 days } \\
\hline $\begin{array}{l}\text { Control } \\
22.2 \mathrm{mmol} / 1 \\
44.4 \mathrm{mmol} / 1\end{array}$ & $\begin{array}{l}9.35 \pm 0.38 \\
5.10 \pm 0.22^{\mathrm{a}} \\
4.32 \pm 0.36^{\mathrm{a}}\end{array}$ & $\begin{array}{l}8.97 \pm 0.73 \\
7.71 \pm 0.66^{\mathrm{a}, \mathrm{b}} \\
7.04 \pm 0.49^{\mathrm{a}, \mathrm{b}}\end{array}$ & $\begin{array}{l}8.43 \pm 0.86 \\
6.98 \pm 0.49^{a, b} \\
6.55 \pm 0.55^{a, b}\end{array}$ & $\begin{array}{l}9.67 \pm 0.86 \\
8.96 \pm 0.67^{b} \\
8.61 \pm 0.90^{b}\end{array}$ \\
\hline \multicolumn{5}{|c|}{ Co-treatment for 10 days } \\
\hline $\begin{array}{l}\text { Control } \\
22.2 \mathrm{mmol} / 1 \\
44.4 \mathrm{mmol} / 1\end{array}$ & $\begin{array}{l}9.28 \pm 0.46 \\
4.51 \pm 0.36^{\mathrm{a}} \\
3.63 \pm 0.31^{\mathrm{a}}\end{array}$ & $\begin{array}{l}8.66 \pm 0.47 \\
7.60 \pm 0.55^{b} \\
7.02 \pm 0.31^{b}\end{array}$ & $\begin{array}{l}8.34 \pm 0.66 \\
7.30 \pm 0.44^{b, c} \\
6.67 \pm 0.45^{b}\end{array}$ & $\begin{array}{l}9.55 \pm 0.77 \\
8.76 \pm 0.57^{b} \\
8.69 \pm 0.85^{b}\end{array}$ \\
\hline
\end{tabular}

Data indicate NO production over 90 min (arbitrary units). BAECs were cultured with the indicated concentrations of glucose for 5 or 10 days in the presence or absence of PKC inhibitors. Bradykinin-induced NO production was measured as described in the Materials and methods section. Values are means \pm SEM of five independent experiments. ${ }^{a} p<0.01$ vs individual control; ${ }^{\mathrm{b}} p<0.01$ vs corresponding glucose concentration with no PKC inhibitor; ${ }^{c} p<0.05$ vs individual control (ANOVA)

Table 2. Reversing high-glucose-induced inhibition of bradykinin-induced increases in $\left[\mathrm{Ca}^{2+}\right]_{\mathrm{i}}$ by PKC inhibitors

\begin{tabular}{|c|c|c|c|c|}
\hline \multirow[t]{2}{*}{ Condition (glucose) } & \multicolumn{4}{|c|}{ Co-treatment } \\
\hline & None & $\begin{array}{l}\text { Bisindolylmaleimide } \\
(10 \mu \mathrm{mol} / \mathrm{l})\end{array}$ & GÖ 6976 (20 nmol/l) & $\begin{array}{l}\text { D- } \alpha \text {-tocopherol } \\
(100 \mu \mathrm{mol} / \mathrm{l})\end{array}$ \\
\hline \multicolumn{5}{|c|}{ Co-treatment for 5 days } \\
\hline Control & $533 \pm 38$ & $502 \pm 36$ & $500 \pm 24$ & $540 \pm 42$ \\
\hline $22.2 \mathrm{mmol} / 1$ & $341 \pm 28^{a}$ & $438 \pm 25^{b}$ & $426 \pm 31^{b}$ & $501 \pm 33^{b}$ \\
\hline \multicolumn{5}{|c|}{ Co-treatment for 10 days } \\
\hline Control & $530 \pm 41$ & $494 \pm 23$ & $495 \pm 21$ & $546 \pm 38$ \\
\hline $22.2 \mathrm{mmol} / 1$ & $210 \pm 28^{c}$ & $453 \pm 27^{b}$ & $433 \pm 30^{b}$ & $491 \pm 27^{b}$ \\
\hline $44.4 \mathrm{mmol} / 1$ & $174 \pm 36^{c}$ & $441 \pm 35^{b}$ & $424 \pm 26^{b}$ & $463 \pm 20^{\mathrm{b}}$ \\
\hline
\end{tabular}

Data indicate $\left[\mathrm{Ca}^{2+}\right]_{\mathrm{i}}(\mathrm{nmol} / \mathrm{l})$. BAECs were cultured with various concentrations of glucose for 5 or 10 days in the presence or absence of PKC inhibitors. Bradykinin-induced increases in $\left[\mathrm{Ca}^{2+}\right]_{\mathrm{i}}$ were determined as described in the Materials and

tion in the number of bradykinin receptors due to high glucose culture. It is known that high glucose may increase diacylglycerol production and thus activate PKC $[12,32,33]$. To study the possibility that the above observed alterations of agonist-induced responses by long-term high glucose culture involved excessive PKC activation, we co-cultured BAECs with cell-permeable PKC inhibitors (Table 1). After 5 days of culture, the effect of 22.2 and $44.4 \mathrm{mmol} / \mathrm{l}$ glucose on bradykinin-induced NO production over 90 min was reversed by $69 \%$ and $60 \%(p<0.05)$ respectively by bisindolylmaleimide-I (a general PKC inhibitor; $10 \mu \mathrm{mol} / \mathrm{l}$ ). Similar reversing effects (by $62 \%$ and $59 \% ; p<0.05)$ were observed when GÖ 6976 (a selective inhibitor of $\mathrm{Ca}^{2+}$-dependent PKC- $\beta$ isoforms; $20 \mathrm{nmol} / \mathrm{l}$ ) was used. In addition, $\mathrm{D}-\alpha$-tocopherol (an antioxidant that could also serve as a general methods section. Values are means \pm SEM of five independent experiments. ${ }^{a} p<0.05$ vs individual control; ${ }^{b} p<0.01$ vs corresponding glucose concentration with no PKC inhibitor; ${ }^{c} p<0.01$ vs individual control (ANOVA)

PKC inhibitor through prevention of diacylglycerol formation, presumably by activating diacylglycerol kinase [12]; $100 \mu \mathrm{mol} / \mathrm{l}$ ) also attenuated the inhibitory effect of 22.2 and $44.4 \mathrm{mmol} / 1$ glucose on bradykinininduced NO generation by $84 \%$ and $80 \%$ respectively $(p<0.05)$. However, a longer period of culture $(10$ days) with these agents only slightly further prevented the impairment of NO production due to 22.2 or $44.4 \mathrm{mmol} / \mathrm{l}$ glucose (Table 1 ).

The observed reduction in agonist-induced increases in $\left[\mathrm{Ca}^{2+}\right]_{\mathrm{i}}$ following high glucose culture were also largely reversed by PKC inhibitors (Table 2). After 5 days of co-culture, bisindolylmaleimide-I reversed the high glucose effect by $65 \%$ and $72 \%(p<0.01)$ at 22.2 and $44.4 \mathrm{mmol} / \mathrm{l}$ glucose respectively, while GÖ 6976 reversed the high glucose effect by $59 \%$ and $70 \%$ $(p<0.01)$ respectively. Likewise, D- $\alpha$-tocopherol was 
Table 3. PKC inhibitors prevent high-glucose-induced reduction of bradykinin receptors

\begin{tabular}{llll}
\hline Condition (glucose) & None & Bisindolylmaleimide $(10 \mu \mathrm{mol} / \mathrm{l})$ & D- $\alpha$-tocopherol $(100 \mu \mathrm{mol} / \mathrm{l})$ \\
\hline Control & $371 \pm 18$ & $336 \pm 22$ & $370 \pm 28$ \\
$22.2 \mathrm{mmol} / \mathrm{l}$ & $264 \pm 14^{\mathrm{a}}$ & $301 \pm 26^{\mathrm{b}}$ & $341 \pm 12^{\mathrm{b}}$ \\
$44.4 \mathrm{mmol} / \mathrm{l}$ & $224 \pm 29^{\mathrm{a}}$ & $288 \pm 14^{\mathrm{a}, \mathrm{b}}$ & $334 \pm 21^{\mathrm{a}, \mathrm{b}}$
\end{tabular}

Data indicate the number of bradykinin receptors $(\mathrm{pmol} / \mathrm{mg}$ protein). BAECs were cultured with the indicated concentrations of glucose for 10 days in the presence or absence of PKC inhibitors. The number of bradykinin receptors was assessed as described in the Materials and methods section. Values are means \pm SEM of five independent experiments. ${ }^{a} p<0.01$ vs individual control; ${ }^{\mathrm{b}} p<0.01$ vs corresponding glucose concentration with no PKC inhibitor (ANOVA) able to reverse the reduced $\left[\mathrm{Ca}^{2+}\right]_{\mathrm{i}}$ increase by $80 \%$ and $77 \%(p<0.05)$ respectively. The reduced $\left[\mathrm{Ca}^{2+}\right]_{\mathrm{i}}$ responses to bradykinin following 10 days of culture with 22.2 or $44.4 \mathrm{mmol} / \mathrm{l}$ glucose were recovered to similar extents in the presence of PKC inhibitors or $D$ - $\alpha$-tocopherol.

Furthermore, co-culture with bisindolylmaleimide-I or $\mathrm{D}-\alpha$-tocopherol was also able to reverse the reduced number of bradykinin receptors in BAECs resulting from 10 days of high glucose culture (Table 3). Bisindolylmaleimide-I reversed the receptor density by $58 \%$ and $61 \%(p<0.01)$ at 22.2 and $44.4 \mathrm{mmol} / 1 \mathrm{glu}-$ cose respectively. $\mathrm{D}-\alpha$-tocopherol reversed the density of the bradykinin receptor by $68 \%$ and $73 \%$ respectively $(p<0.01)$.

\section{Discussion}

It has been speculated that chronic exposure to high glucose could cause the impairment of NO release and/or the increased destruction of released NO following stimulation by PLC-activating agonists $[4,34$, $35]$. In the current study, we provide strong evidence that the $\mathrm{IP}_{3}-\mathrm{Ca}^{2+}-\mathrm{NO}$ cascade pathway is impaired in endothelial cells exposed to prolonged high glucose in a time- and dose-dependent manner. Although this paper only provides detailed data using a single type of endothelial cell (BAECs) and one receptor agonist (bradykinin), we also found that high glucose culture had identical effects on NO production and $\left[\mathrm{Ca}^{2+}\right]_{i}$ profile when ATP was used as a PLC-activating agonist and when HUVECs were studied [36].

Our data revealed that the impairments by high glucose of both $\mathrm{NO}$ formation and $\left[\mathrm{Ca}^{2+}\right]_{\mathrm{i}}$ are specific to the PLC-activating receptor agonists such as bradykinin and ATP, and that they do not impede the actions of $\mathrm{Ca}^{2+}$ ionophore. These results are consistent with the observations of studies of diabetic animals and patients in which the impaired endothelium-dependent vasodilation occurred only after the stimulation with receptor agonists such as acetylcholine and bradykinin, but not following the application of $\mathrm{NO}$ donors or $\mathrm{Ca}^{2+}$ ionophores $[2,3,6,9]$. Thus, a deficiency in NO, rather than a change in the sensitivity of vascular smooth muscle cells to NO, contributes to the im- paired endothelium-dependent vasodilation in diabetes.

The fact that exposure to high glucose of up to 10 days did not alter eNOS mass in either cultured BAECs or HUVECs (data not shown) points to an impairment of the activation of eNOS in endothelial cells following protracted high glucose culture. Physiologically, eNOS in endothelial cells is activated by two major modes [4]. One is the longitudinal shear force on the endothelium. The detail in the mechano-transduction for this activation mode is unclear, though this action may be mediated via integrins and $G$ proteins and may involve tyrosine phosphorylation and protein kinase B (Akt) [17, 37, 38]. The other mode for the activation of eNOS is the stimulation of cell surface receptors that activate G-protein-coupled PLC resulting in an increase in $\left[\mathrm{Ca}^{2+}\right]_{i}[18,19,20,21,31]$. Although the experiments carried out in cell-free systems indicated a role of $\mathrm{Ca}^{2+}$ in eNOS activation, the importance of $\mathrm{Ca}^{2+}$ in such an event by PLC-stimulating agonists in the intact cells is uncertain. Using ionomycin to set $\left[\mathrm{Ca}^{2+}\right]_{i}$ at different levels, we were able to demonstrate that the amount of NO production was well correlated with the extent of $\left[\mathrm{Ca}^{2+}\right]_{\mathrm{i}}$ elevation in living endothelial cells. A close association of the extent of an increase in endothelial $\left[\mathrm{Ca}^{2+}\right]_{i}$ with agonist-induced relaxation was also found in the rabbit aortic valve [39]. Importantly, bradykinin-stimulated NO generation depends on $\mathrm{Ca}^{2+}$ (Fig. 2d). These findings strongly indicate that a change in $\left[\mathrm{Ca}^{2+}\right]_{\mathrm{i}}$ elevation by PLC-coupled receptor agonists may lead to an alteration in $\mathrm{NO}$ formation.

A few studies on cultured endothelial cells at high glucose for a short period (up to 2 days) have revealed alterations in $\left[\mathrm{Ca}^{2+}\right]_{\mathrm{i}}$ homeostasis $[7,22,23]$. However, the results of these studies are not consistent. In porcine aortic endothelial cells, 1 day of culture with high glucose $(44 \mathrm{mmol} / \mathrm{l})$ caused enhanced increases in $\left[\mathrm{Ca}^{2+}\right]_{\mathrm{i}}$ in response to bradykinin $[7,22]$, whereas an opposing effect was observed in another study when BAECs were exposed to $25 \mathrm{mmol} / \mathrm{l}$ glucose for $24 \mathrm{~h}$ [23]. In our study, 2 days of culture in high glucose did not affect bradykinin-induced increases in $\left[\mathrm{Ca}^{2+}\right]_{\mathrm{i}}$ in endothelial cells. However, the development of a dysfunctional vascular endothelium in diabetic subjects involves chronic exposure to high glucose en- 
vironments. Thus, we performed thorough experiments to examine the effects of longer periods of culture (5 or 10 days) at two high glucose concentrations on $\left[\mathrm{Ca}^{2+}\right]_{\mathrm{i}}$ homeostasis in endothelial cells. Both bradykinin-induced $\mathrm{Ca}^{2+}$ mobilisation and $\mathrm{Ca}^{2+}$ influx were clearly affected by high glucose in a dose- and time-dependent manner (Fig. 4). The only paper available in the literature studying long-term effects of high glucose on $\left[\mathrm{Ca}^{2+}\right]_{\mathrm{i}}$ in endothelial cells also reported that 3 to 6 days of high glucose culture inhibited increases in $\left[\mathrm{Ca}^{2+}\right]_{\mathrm{i}}$ induced by bradykinin and ATP in porcine aortic endothelial cells [8]. PLC-activating agonists increase $\left[\mathrm{Ca}^{2+}\right]_{i}$ in endothelial cells both through $\mathrm{IP}_{3}$-mediated $\mathrm{Ca}^{2+}$ release from intracellular $\mathrm{Ca}^{2+}$ stores and through stimulated $\mathrm{Ca}^{2+}$ entry from extracellular space $[19,20]$. It is generally accepted that agonist-promoted $\mathrm{Ca}^{2+}$ entry is attributable to the depletion of $\mathrm{IP}_{3}$-sensitive $\mathrm{Ca}^{2+}$ stores, and this type of $\mathrm{Ca}^{2+}$ entry is thus called store-operated $\mathrm{Ca}^{2+}$ influx, or capacitative $\mathrm{Ca}^{2+}$ entry $[20,40]$. It has been reported that both $\mathrm{Ca}^{2+}$ mobilisation and $\mathrm{Ca}^{2+}$ influx are important for eNOS activation by agonists. $\mathrm{Ca}^{2+}$ release from intracellular stores was required for the activation of eNOS by flow and agonists in aorta [31]. Other studies have found that sustained eNOS activation in endothelial cells by agonists required capacitative $\mathrm{Ca}^{2+}$ entry $[41,42]$. Our data also show that sustained eNOS activation by bradykinin is dependent on $\mathrm{Ca}^{2+}$ entry (Fig. 2d), suggesting that the attenuation of capacitative $\mathrm{Ca}^{2+}$ entry may be the quantitatively most critical event contributing to the inhibition of NO production in endothelial cells after chronic high glucose culture. However, it appears that such attenuated $\mathrm{Ca}^{2+}$ influx is not due to an impairment of capacitative $\mathrm{Ca}^{2+}$ entry per se, but rather to a decline in the driving force for this $\mathrm{Ca}^{2+}$ store-operated process. Two lines of evidence support this notion. First, bradykinin-stimulated $\mathrm{IP}_{3}$ production and bradykinin-induced $\mathrm{Ca}^{2+}$ mobilisation were significantly reduced in high-glucose-cultured endothelial cells and thus the $\mathrm{IP}_{3}$-sensitive $\mathrm{Ca}^{2+}$ pool has a less-depleted status and in turn attenuated capacitative $\mathrm{Ca}^{2+}$ entry. Second, increases in $\left[\mathrm{Ca}^{2+}\right]_{\mathrm{i}}$ in endothelial cells, induced by thapsigargin, were not affected by chronic high glucose culture, indicating that the store-operated capacitative $\mathrm{Ca}^{2+}$ entry functions normally and that $\mathrm{IP}_{3}$-sensitive $\mathrm{Ca}^{2+}$ stores remain intact.

Our results revealed that high glucose culture attenuated both basal and bradykinin-stimulated $\mathrm{IP}_{3}$ production in endothelial cells, which does not seem to be due to a reduction of inositol phospholipids (the PLC substrates). Although the reduced $\mathrm{IP}_{3}$ production could be the result of a defect at any level in the coupling of receptor, G protein and PLC, our data demonstrated for the first time that there was a decrease in the number of receptors in endothelial cells following long-term exposure to high glucose. Importantly, such a reduction in the number of receptors could affect ag- onist-induced responses/function in cells, leading to the observed impairments of $\left[\mathrm{Ca}^{2+}\right]_{\mathrm{i}}$ responses and $\mathrm{NO}$ production upon bradykinin stimulation. Indeed, a $33 \%$ reduction in the number of receptors due to $\mathrm{PKC}$ activation induced a proportional decrease of bradykinin-mediated $\mathrm{IP}_{3}$ formation in fibroblasts [21], and a $40 \%$ down-regulation of arginine vasopressin receptors in high-glucose-cultured vascular smooth muscle cells resulted in a similar extent of inhibition of arginine-vasopressin-induced $\left[\mathrm{Ca}^{2+}\right]_{\mathrm{i}}$ elevations [43]. Whether high glucose is also able to reduce the number of other receptors (e.g. purinergic receptors) in endothelial cells remains to be clarified.

What are the mechanisms by which high glucose induces the reduction in the number of receptors, as well as the inhibition of PLC, the impairment of $\left[\mathrm{Ca}^{2+}\right]_{i}$ profile, and the attenuation of eNOS activation in BAECs? Earlier studies showed that acute PKC activation has a negative feedback effect on the pathway linking receptors to PLC stimulation [43, 44, 45]. Furthermore, PKC (especially $\beta$ and $\delta$ isoforms) is excessively activated in high glucose environments due to enhanced de novo synthesis of diacylglycerol [12, 32, 33]. Our results using PKC inhibitors suggest that excessive PKC activation is a candidate mechanism for the alterations in $\mathrm{NO}$ production, $\left[\mathrm{Ca}^{2+}\right]_{\mathrm{i}}$ elevation and PLC activation in response to agonists in endothelial cells chronically exposed to high glucose. This notion is also applicable to the reduction in the number of bradykinin receptors under the same conditions. Similarly, the PKC inhibitor reversed high-glucose-induced down-regulation of the numbers of angiotensin II and arginine vasopressin receptors in vascular smooth muscle cells [43]. How PKC activation causes receptor down-regulation is unclear, but one possibility is through the suppression of mRNA expression [46]. It should be noted that the PKC inhibitors (bisindolylmaleimide and GÖ 6976) cannot completely reverse the impairments due to high glucose, while D- $\alpha$-tocopherol (also a well-known antioxidant) appears to be more efficient than the typical PKC inhibitors. This suggests that oxidation may be also implicated in the pathogenesis of high-glucose-induced impairments of NO formation and the related signalling pathway. Indeed, an increase in the generation of reactive oxygen species and oxidation stress occurs in vessels following exposure to high glucose, or in diabetes [47, 48]. Our findings shed light on the clinical observations using antioxidants and PKC inhibitors that are able to improve or prevent diabetes-induced vascular damage including impaired endothelium-dependent vasodilation $[10,11,12,13]$.

In summary, our studies provide novel information on the pathogenesis of a dysfunctional endothelium in diabetes, indicating that chronic exposure of endothelial cells to high glucose reduces bradykinin-stimulated $\mathrm{NO}$ production by impairing $\mathrm{IP}_{3}-\mathrm{Ca}^{2+}$ signal transduction, at least partly, at the receptor level that involves 
PKC and maybe also oxidation. This could be a molecular mechanism underlying the reduction of endothelium-dependent vasodilation observed in hyperglycaemic states, and thus these findings may improve our understanding of the development of vascular complications in diabetes mellitus. Our data have also clearly indicated the significance of the function of the endothelium in vivo in response to an external stimulus.

Acknowledgements. We thank S.A. Metz for critical reading and for comments to this paper. Y. Tang is a recipient of a Research Scholarship from the National University of Singapore. This work was supported by grants (R-364-000-012-213, NMRC/0540/2001 and NMRC/0803/2003) from the National Medical Research Council of Singapore (to G.D. Li).

\section{References}

1. Laakso M (1999) Hyperglycemia and cardiovascular disease in type 2 diabetes. Diabetes 48:937-942

2. Durante W, Sen AK, Sunahara FA (1988) Impairment of endothelium-dependent relaxation in aortae from spontaneously diabetic rats. Br J Pharmacol 94:463-468

3. Karasu C, Altan VM (1993) The role of endothelial cells on the alterations in vascular reactivity induced by insulindependent diabetes mellitus: effects of insulin treatment. Gen Pharmacol 24:743-755

4. Wennmalm A (1994) Endothelial nitric oxide and cardiovascular disease. J Intern Med 235:317-327

5. McVeigh GE, Brennan GM, Johnston GD et al. (1992) Impaired endothelium-dependent and independent vasodilation in patients with type 2 (non-insulin-dependent) diabetes mellitus. Diabetologia 35:771-776

6. Johnstone MT, Caulfield TA (2001) Nitric oxide and its role in diabetes mellitus. In: Johnstone MT, Veves A (eds) Diabetes and cardiovascular disease. Human Press, Totowa, New Jersey, pp 213-236

7. Graier WF, Wascher TC, Lackner L et al. (1993) Exposure to elevated D-glucose concentrations modulates vascular endothelial cell vasodilatory response. Diabetes 42:1497-1505

8. Salameh A, Dhein S (1998) Influence of chronic exposure to high concentrations of D-glucose and long-term betablocker treatment on intracellular calcium concentrations of porcine aortic endothelial cells. Diabetes 47:407-413

9. Pieper GM (1999) Enhanced, unaltered and impaired nitric oxide-mediated endothelium-dependent relaxation in experimental diabetes mellitus: importance of disease duration. Diabetologia 42:204-213

10. Way KJ, Katai N, King GL (2001) Protein kinase C and the development of diabetic vascular complications. Diabet Med 18:945-959

11. Beckman JA, Goldfine AB, Gordon MB, Garrett LA, Creager MA (2002) Inhibition of protein kinase $C$ beta prevents impaired endothelium-dependent vasodilation caused by hyperglycemia in humans. Circ Res 90:107-111

12. Meier M, King GL (2000) Protein kinase C activation and its pharmacological inhibition in vascular disease. Vasc Med 5:173-185

13. Laight DW, Carrier MJ, Anggard EE (2000) Antioxidants, diabetes and endothelial dysfunction. Cardiovasc Res 47: 457-464

14. Moncada S, Palmer RM, Higgs EA (1991) Nitric oxide: physiology, pathophysiology, and pharmacology. Pharmacol Rev 43:109-142
15. Govers R, Rabelink TJ (2001) Cellular regulation of endothelial nitric oxide synthase. Am J Physiol Renal Physiol 280:F193-F206

16. Busse R, Trogisch G, Bassenge E (1985) The role of endothelium in the control of vascular tone. Basic Res Cardiol 80:475-490

17. Fleming I, Busse R (1999) Signal transduction of eNOS activation. Cardiovasc Res 43:532-541

18. Rubanyi GM, Vanhoutte PM (1988) Calcium and activation of the release of endothelium-derived relaxing factor. Ann N Y Acad Sci 522:226-233

19. Freay A, Johns A, Adams DJ, Ryan US, Van Breemen C (1989) Bradykinin and inositol 1,4,5-trisphosphate-stimulated calcium release from intracellular stores in cultured bovine endothelial cells. Pflugers Arch 414:377-384

20. Putney JW Jr, Broad LM, Braun FJ, Lievremont JP, Bird GS (2001) Mechanisms of capacitative calcium entry. J Cell Sci 114:2223-2229

21. Huang HM, Gibson G (1996) Regulation of bradykinin-induced Ins $(1,4,5) \mathrm{P} 3$ formation by protein kinase $\mathrm{C}$ in human fibroblasts. Life Sci 59:1533-1543

22. Wascher TC, Toplak H, Krejs GJ et al. (1994) Intracellular mechanisms involved in D-glucose-mediated amplification of agonist-induced $\mathrm{Ca}^{2+}$ response and EDRF formation in vascular endothelial cells. Diabetes 43:984-991

23. Pieper GM, Dondlinger L (1997) Glucose elevations alter bradykinin-stimulated intracellular calcium accumulation in cultured endothelial cells. Cardiovasc Res 34:169-178

24. Hornig B, Drexler H (1997) Endothelial function and bradykinin in humans. Drugs 54 [Suppl 5]:42-47

25. Nakatsubo N, Kojima H, Kikuchi K et al. (1998) Direct evidence of nitric oxide production from bovine aortic endothelial cells using new fluorescence indicators: diaminofluoresceins. FEBS Lett 427:263-266

26. Huo JX, Metz SA, Li GD (2004) p53-independent induction of $\mathrm{p} 21$ (waf1/cip1) contributes to the activation of caspases in GTP-depletion-induced apoptosis of insulinsecreting cells. Cell Death Differ 11:99-109

27. Li GD, Milani D, Dunne MJ et al. (1991) Extracellular ATP causes $\mathrm{Ca}^{2+}$-dependent and -independent insulin secretion in RINm5F cells. Phospholipase $\mathrm{C}$ mediates $\mathrm{Ca}^{2+}$ mobilization but not $\mathrm{Ca}^{2+}$ influx and membrane depolarization. J Biol Chem 266:3449-3457

28. Limbird LE (1996) Cell surface receptors: a short course on theory and methods. Kluwer Academic Publishers, Boston

29. Linseman DA, Sorensen SD, Fisher SK (1999) Attenuation of focal adhesion kinase signaling following depletion of agonist-sensitive pools of phosphatidylinositol 4,5-bisphosphate. J Neurochem 73:1933-1944

30. Medh JD, Weigel PH (1989) Separation of phosphatidylinositols and other phospholipids by two-step one-dimensional thin-layer chromatography. J Lipid Res 30: 761-764

31. Hutcheson IR, Griffith TM (1997) Central role of intracellular calcium stores in acute flow- and agonist-evoked endothelial nitric oxide release. Br J Pharmacol 122:117-125

32. King GL, Ishii H, Koya D (1997) Diabetic vascular dysfunctions: a model of excessive activation of protein kinase C. Kidney Int [Suppl 60]:S77-S85

33. Koya D, King GL (1998) Protein kinase C activation and the development of diabetic complications. Diabetes 47:859-866

34. Ding Y, Vaziri ND, Coulson R, Kamanna VS, Roh DD (2000) Effects of simulated hyperglycemia, insulin, and glucagon on endothelial nitric oxide synthase expression. Am J Physiol Endocrinol Metab 279:E11-E17 
35. Cosentino F, Hishikawa K, Katusic ZS, Luscher TF (1997) High glucose increases nitric oxide synthase expression and superoxide anion generation in human aortic endothelial cells. Circulation 96:25-28

36. Tang YX, Li GD (2003) Prolonged culture with high glucose causes a reduction in the number of bradykinin receptor in endothelial cells via activation of protein kinase C- $\beta$. Diabetes 52 [Suppl 1]:A168 (Abstract)

37. Griffith TM (1999) Shear stress and nitric oxide release: physiological integration of cellular mechanisms, physical forces and flow regulation. In: Mathie RT, Griffith TM (eds) The haemodynamic effects of nitric oxide. Imperial College Press, London, pp 22-51

38. Corson MA, James NL, Latta SE et al. (1996) Phosphorylation of endothelial nitric oxide synthase in response to fluid shear stress. Circ Res 79:984-991

39. Amano K, Hori M, Ozaki H, Karaki H (1999) Agonist-dependent difference in the relationship between cytosolic $\mathrm{Ca}^{2+}$ level and release of vascular relaxing factors in the endothelium of rabbit aortic valve. Eur J Pharmacol 366:215-221

40. Trebak M, Bird GS, McKay RR, Putney JW Jr (2002) Comparison of human TRPC3 channels in receptor-activated and store-operated modes. Differential sensitivity to channel blockers suggests fundamental differences in channel composition. J Biol Chem 277:21617-21623

41. Lin S, Fagan KA, Li KX et al. (2000) Sustained endothelial nitric-oxide synthase activation requires capacitative $\mathrm{Ca}^{2+}$ entry. J Biol Chem 275:17979-17985
42. Lantoine F, Iouzalen L, Devynck MA, Millanvoye-Van Brussel E, David-Dufilho M (1998) Nitric oxide production in human endothelial cells stimulated by histamine requires $\mathrm{Ca}^{2+}$ influx. Biochem J 330:695-699

43. Williams B, Tsai P, Schrier RW (1992) Glucose-induced downregulation of angiotensin II and arginine vasopressin receptors in cultured rat aortic vascular smooth muscle cells. Role of protein kinase C. J Clin Invest 90:1992-1999

44. Ryu SH, Kim UH, Wahl MI et al. (1990) Feedback regulation of phospholipase C-beta by protein kinase C. J Biol Chem 265:17941-17945

45. Brock TA, Capasso EA (1988) Thrombin and histamine activate phospholipase $\mathrm{C}$ in human endothelial cells via a phorbol ester-sensitive pathway. J Cell Physiol 136:54-62

46. Martin KA, Kertesy SB, Dubyak GR (1997) Down-regulation of P2U-purinergic nucleotide receptor messenger RNA expression during in vitro differentiation of human myeloid leukocytes by phorbol esters or inflammatory activators. Mol Pharmacol 51:97-108

47. Giugliano D, Ceriello A, Paolisso G (1996) Oxidative stress and diabetic vascular complications. Diabetes Care 19:257-267

48. Tesfamariam B, Cohen RA (1992) Free radicals mediate endothelial cell dysfunction caused by elevated glucose. Am J Physiol 263:H321-H326 